\title{
Enhancement the Growth and Phenolic Content of Faba Bean (Vicia faba L.) by Applying Some Biofertilizer
}

\author{
Agents
}

Ragaa, A. Hamouda

Microbial Biotechnology Department

Genetic Engineering and Biotechnology Research Institute (GEBRI)

El-Sadat City University, Egypt

Safinaz, A. Farfour (Corresponding author)

Environmental Biotechnology Department

Genetic Engineering and Biotechnology Research Institute (GEBRI)

El-Sadat City University, Egypt

Received: Oct. 6, 2013 Accepted: November 18, $2013 \quad$ Published: December 1, 2013

doi:10.5296/jfs.v2i2.4425 URL: http://dx.doi.org/10.5296/jfs.v2i2.4425

\begin{abstract}
Some microorganisms, i.e., Rhizobium leguminosarum var. faba, Aphanocapsa albida and Laurencia obtusa, were applied in pots to enhance the growth of faba bean (Vicia faba L.) plants. The individual and combined microorganisms applications significantly increased the plant height and number of leaves at the early growth stages. Ninety days after planting, all the treatments significantly enhanced the plant growth parameters. Laurencia obtusa + Aphanocapsa albida increased the whole plant length, dry weight, total phenols content and nitrogen content by $46.3 \%, 96.5 \%, 315 \%$ and $86 \%$ respectively. However while the combination between the three microorganisms increased whole plant fresh weight by $56.0 \%$ in comparison with control.
\end{abstract}

Keywords: Faba bean, Cyanobacteria, Rhizobium, Marine algae, Phenolic content 


\section{Introduction:}

Faba (Vicia faba L., ) bean is an annual legume which also known botanically as also known as the broad bean, fava bean, faba bean, field bean, bell bean, or tic bean, is a species of bean (Fabaceae) native to north Africa, southwest and south Asia, and extensively cultivated elsewhere. Faba bean roots need to be inoculated with the appropriate strains of rhizobia (Rhizobium leguminsarium), which will infect the plants root and stimulates root nodule development. This occurs when the faba beans are being grown in the field for the first time or where they have not been grown for long time.

Biofertilizers are the micro-organisms and their products which are utilized to increase soil fertility. The N2 - fixing micro-organisms are Anabaena, Nostoc, Rhizobia, Tolypothrix etc. Biofertilizers are products containing living cells of different types of microorganisms which when applied to seeds, plant surface or soil, colonize the rhizosphere or the interior of the plant and promotes growth by converting nutritionally important elements (nitrogen and phosphorus) from unavailable to available form through biological process such as nitrogen fixation and solubilization of rock phosphate (Rokhzadi et al., 2008). El-Yazid et al. (2007) found that beneficial microorganisms in biofertilizers accelerate and improve plant growth and protect plants from pests and diseases.

The property of symbiotically fixing nitrogen within nodules of vascular plants is found in two major groups of bacteria one of them, rhizobia that associate essentially with leguminous, (Sprent, 2007). Another important group of nitrogen fixing bacteria is that of the cyanobacteria, found in association with a large variety of higher and lower plants, fungi and algae. (Meeks and Elhai, 2002). Franche et al. (2009) reported that leguminous plants can obtain their nitrogen by association with rhizobia via differentiation on their respective host plants of a specialized organ, the root nodules. Bhattacharyya and Pati, (2000) found that Rhizobium sp., produced high amount $(107 \mu \mathrm{g} / \mathrm{ml})$ of IAA in culture from tryptophan supplemented Yeast Extract Mannitol medium. The production was maximum when the bacteria reached its stationary phase of growth.

Other symbiotic associations involve hetero-cystous cyanobacteria, while increasing numbers of nitrogen-fixing species have been identified as colonizing the root surface and, in some cases, the root interior of a variety of cereal crops and pasture grasses. Kevin Vessey, (2003) found that rhizobacteria when used as biofertilizer can influence root growth, morphology and other beneficial plant microbe symbioses. Cyanobacteria are one of the major components of the nitrogen fixing biomass in paddy fields. Due to the important characteristic of nitrogen fixation, cyanobacteria have a unique potential to contribute to enhance productivity in a variety of agricultural and ecological situations. It plays an important role to build up soil fertility consequently increasing in the yield, ( Sahu et al., 2012 and Song et al., 2005).

Thirumaran et al. (2009) stated that recent researches proved that seaweed fertilizers are preferred not only due to their nitrogen, phosphorus and potash content but also because of the presence of trace elements and metabolite similar to plant growth regulators. Recently, seaweed extracts as liquid fertilizers (SLF) has come in the market for the simple reason that 
they contain many growth promoting hormones like auxin, gibberellin, trace elements, vitamins, amino acids and micronutrients. Strik et al. (2004) reported that the seaweeds extracts are effective fertilizers in many crops.

The objectives of this study are to observe the effect of individual and combined Rhizobium leguminosarum var, faba, Aphanocapsa albida and Laurencia obtusa applications on the growth, total phenols content and nitrogen content of faba bean (Vicia faba L.).

\section{Materials and Methods}

\section{Rhizobium preparation}

Commercial formula known as "Okkadeen" biofertilizer contained Rhizobium leguminosarum var. faba was obtained from Legume Crops Dept., Field Crops Research Institute, A R C, Giza, Egypt.

One gm of the Okkadeen biofertilizer was suspended in $100 \mathrm{ml}$ sterilized distilled water and shacked well. Serial dilutions were made by taking a loop of each of them to $100 \mathrm{ml}$ sterilized distilled water. A loop from $10^{-9}$ dilution was transferred to $100 \mathrm{ml}$ Yeast Extract Manitol "YEM" medium and incubated in a water bath shaker at $25^{\circ} \mathrm{C} \pm 1$ for 72 hrs. Seeds were immersed in sugar solution; as an adhesive material; prepared by dissolving 20 gm of sugar in $100 \mathrm{ml}$ water. Treated seeds were then mixed thoroughly with the "Okadeen" biofertilizer and left for $30 \mathrm{~min}$. in a shadow place for drying before cultivation.

\section{Algae collection and preparation}

Laurencia obtusa was collected in May, 2011 from shallow water beside the shore of Red Sea at Safaga. After collection, algae were washed with fresh sea water to remove the epiphytes, sand and other extraneous matter then they were dried in shadow open air and completing the drying process in the oven at $60^{\circ} \mathrm{C}$ for 5 hours. Then, dried algae were ground to fine powder by mechanic grinder. The algae were applied as a soil treatment at the rate of 3 gm powdered algae/Kg soil seven days before planting and watered twice daily.

The blue green algae, Aphanocapsa albida were isolated from soil. Isolation and purification of algae were done according to the method described by Rippka, (1988). Algae were isolated after repeated light migrations on solid BG11, medium, (Zarrouk, 1966 and Stainer et al., 1971). They were grown in Erlenmeyer flasks $(500 \mathrm{ml})$ in axenic conditions. The cultures were incubated in the room temperature of approx $25 \pm 2^{\circ} \mathrm{C}$ and a light intensity 2500 lux. provided by cool, white, fluorescent tubes under continuous illumination for 15 days. Two hundred $\mathrm{ml}$. from the culture was added to the pots after planting.

\section{Plant material}

Seeds of Faba bean (Vicia faba L.) cv. Sakha1 were surface sterilized with ethanol $70 \%$ and washed by sterile distilled water, then dried in shadow open air.

The seeds were planted in $30 \mathrm{~cm}$ diameter earthen pots containing mixture of 1:1 autoclaved peat and sand soil. Every pot contained 2 seeds. They watered every week. 


\section{Macrothink}

Journal of Food Studies

ISSN 2166-1073

2013, Vol. 2, No. 2

\section{Growth measurements}

Plant height and number of leaves were recorded at different growth stages. At the end of the experiment; plant height, plant fresh weight, plant dry weight, $\mathrm{N}$ - content and Phenol content were recorded.

\section{The treatments}

1-Control, 2- Rhizobium leguminosarum var, faba, 3- Aphanocapsa albida , 4- Laurencia obtusa + Aphanocapsa albida, 5- Rhizobium leguminosarum var, faba + Aphanocapsa albida ,6- Rhizobium leguminosarum var, faba + Laurencia obtusa + Aphanocapsa albida.

\section{Chemical analysis}

\section{1-Determination of total phenolics content (TPC)}

The determination of total phenolics content (TPC) was estimated spectrophotometrically by using Folin-Ciocalteu reagent as described by (Singleton and Rossi, 1965). The absorbance was measured at $750 \mathrm{~nm}$ and compared to gallic acid calibration curve. The TPC was calculated by comparing the absorbance with the gallic acid calibration curve according to the formula:

$\mathrm{TPC}(\mathrm{mg} / \mathrm{g})=\mathrm{C}$ x V/g where;

$\mathrm{C}=$ concentration of the gallic acids equivalent from standard curve $(\mathrm{mg} / \mathrm{mL})$

$\mathrm{V}=$ volume of the extract used (ml)

$\mathrm{g}=$ weight of extract $(\mathrm{g})$

The contents were expressed as gallic acids (mg GAE/g dry wt).

\section{2- Determination of $\mathbf{N}$-content}

The determination of total nitrogen was carried out with Micro-Kjeldahel method. (Anonymous 1990). Oh point five $\mathrm{g}$ of dried and finely ground shoot and root sample was taken in a Kjeldahl flask. Three $\mathrm{g}$ of digestion mixture $\left(\mathrm{H}_{2} \mathrm{SO}_{4}+\mathrm{K}_{2} \mathrm{SO}_{4}\right)$ in the ratio of 1:9 was added and followed by $20 \mathrm{ml}$ of $\mathrm{H}_{2} \mathrm{SO}^{4}$. The sample was boiled in digestion apparatus for 1.5-2 hrs. until the contents became clear. The digested material was cooled and diluted up to $250 \mathrm{ml}$ in a volumetric flask by adding distilled water. An aliquot $10 \mathrm{ml}$ of it was transferred to the micro Kjeldahl distillation apparatus. It was mixed with $10 \mathrm{ml}$ of $40 \%$ $\mathrm{NaOH}$ and distilled in a receiver containing $10 \mathrm{ml}$ of $2 \%$ boric acid solution with methyl red as indicator. The contents of the distillate were titrated against standard sulfuric acid $(\mathrm{N} / 10$ $\mathrm{H}_{2} \mathrm{SO}_{4}$ ) to light pink color end point. From the volume of acid used, percentage of nitrogen was calculated based on ammonia liberated.

\section{Statistical analysis}

The responses of the treatments were compared by analysis of variance (ANOVA) (Sokal and Rohlf, 1995). Significant differences between the means of parameters were determined by 


\section{Macrothink}

Journal of Food Studies ISSN 2166-1073 2013, Vol. 2, No. 2

using Duncan's multiple range tests $(\mathrm{P} \leq 0.05)$. All analysis was carried out with Spss software.

\section{Results}

Rhizobium leguminosarum var. faba, Laurencia obtusa and Aphanocapsa albida and their combinations were used to study their effect as biofertilizers agents to enhance the growth of Faba bean (Vicia faba L.,). In Vivo. Studies; it could be noticed that the application of Rhizobium leguminosarum var. faba + Aphanocapsa albida caused significant increase in plant height after 15 days (Fig., 1) while Laurencia obtusa + Aphanocapsa albida gave the best results after 30, 45, 60 and 75 days in comparison with control.

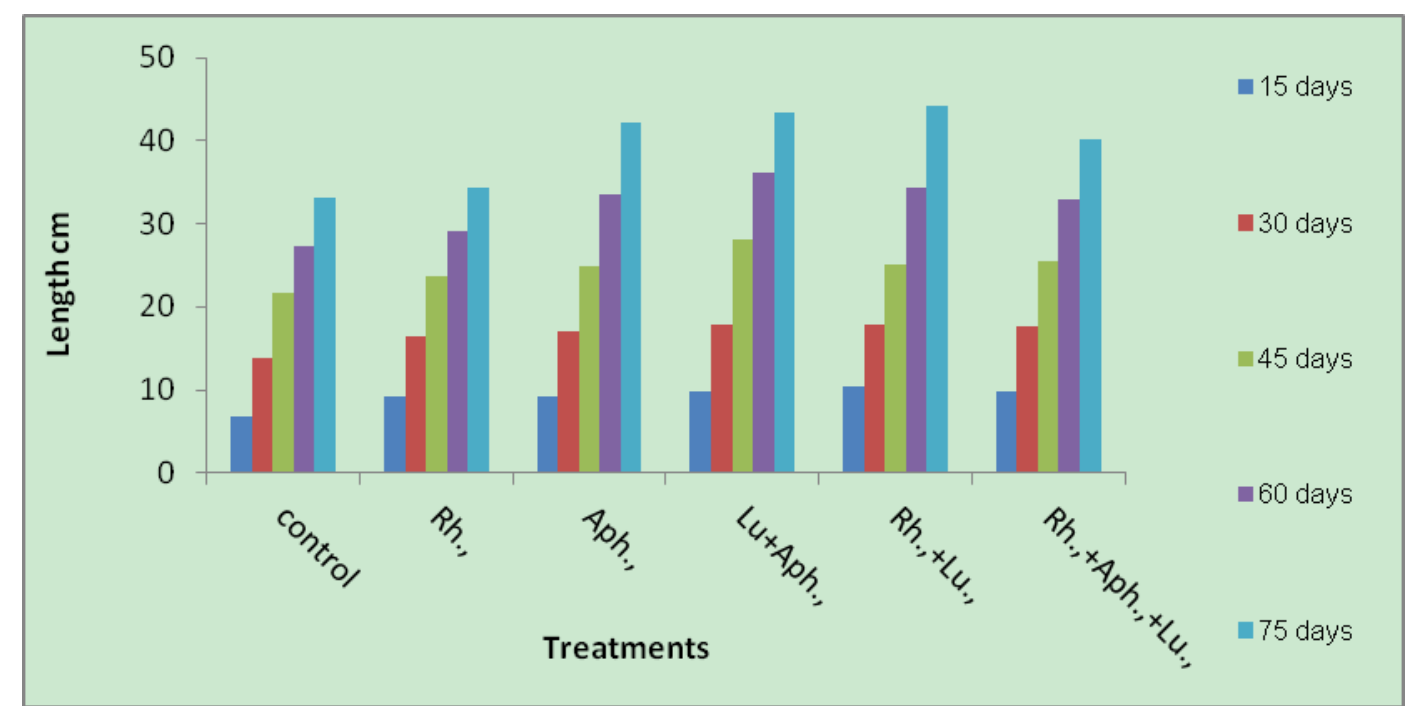

Figure 1. Effect of some biofertilizer agents on plant height of faba bean (Vicia faba L.)

Results in table 1 clear that number of leaves after 15, 30, 45, 60 and 75 days was increased in response to variable treatments in comparison with control. Application of Rhizobium leguminosarum var. faba + Laurencia obtusa + Aphanocapsa albida gave the same result of control. Generally it could be noticed that Laurencia obtusa + Aphanocapsa albida and Rhizobium leguminosarum var, faba + Laurencia obtusa were the best treatment for plant growth at the early stages from planting. 
Table 1. Effect of some biofertilizers agents on leaves number of faba bean (Vicia faba L.)

\begin{tabular}{|l|l|l|l|l|l|}
\hline \multirow{2}{*}{ Treatments } & \multicolumn{5}{l}{ Leaves number } \\
\cline { 2 - 6 } & $\mathbf{1 5}$ days & $\mathbf{3 0}$ days & $\mathbf{4 5}$ days & $\mathbf{6 0}$ days & $\mathbf{7 5}$ days \\
\hline Control & $6.6 \mathrm{a}$ & $8.30 \mathrm{a}$ & $10.0 \mathrm{a}$ & $11.2 \mathrm{a}$ & $12.5 \mathrm{a}$ \\
\hline Rh., & $8.0 \mathrm{~b}$ & $9.5 \mathrm{ab}$ & $11.0 \mathrm{ab}$ & $12.1 \mathrm{ab}$ & $13.2 \mathrm{ab}$ \\
\hline Aph., & $8.0 \mathrm{~b}$ & $9.2 \mathrm{ab}$ & $10.5 \mathrm{ab}$ & $12.1 \mathrm{ab}$ & $13.7 \mathrm{~b}$ \\
\hline Lu.,+Aph., & $8.0 \mathrm{~b}$ & $9.6 \mathrm{~b}$ & $11.2 \mathrm{ab}$ & $12.5 \mathrm{ab}$ & $13.8 \mathrm{~b}$ \\
\hline Rh.,+ Lu., & $7.9 \mathrm{~b}$ & $10.4 \mathrm{~b}$ & $13.0 \mathrm{~b}$ & $13.5 \mathrm{~b}$ & $14.0 \mathrm{~b}$ \\
\hline Rh.,+ Aph., +Lu., & $8.0 \mathrm{~b}$ & $9.6 \mathrm{~b}$ & $11.2 \mathrm{ab}$ & $11.8 \mathrm{a}$ & $12.5 \mathrm{a}$ \\
\hline L S D & .043 & .014 & .136 & .024 & .003 \\
\hline
\end{tabular}

Rh.,:Rhizobium Aph.,: Aphanocapsa $\quad$ Lu.,: Laurencia

The criteria based on plant length, fresh and dry weight, $\mathrm{N}$ - content and total phenol content were calculated after 90 days from planting (flowering stage). Average length of shoot, root and whole plant are shown in table 2 which clear that all the treatments increased the whole plant length (21.6-46.3\%). Application of Laurencia obtusa + Aphanocapsa albida caused the best increase of shoot, root and whole plant length, (46.2) in comparison with control.

Table 2. Effect of some biofertilizers agents on length $(\mathrm{cm})$ of faba bean (Vicia faba L.)

\begin{tabular}{|l|l|l|l|l|}
\hline \multirow{2}{*}{ Treatments } & \multicolumn{4}{l}{ length $(\mathbf{c m})$} \\
\cline { 2 - 5 } & Shoot & Root & Total plant & Increasing\% \\
\hline Control & $37.2 \mathrm{a}$ & $22.4 \mathrm{a}$ & $59.6 \mathrm{a}$ & - \\
\hline Rh., & $40.0 \mathrm{ab}$ & $32.5 \mathrm{~b}$ & $72.5 \mathrm{ab}$ & 21.6 \\
\hline Aph., & $45.5 \mathrm{~d}$ & $29.4 \mathrm{ab}$ & $74.9 \mathrm{ab}$ & 25.6 \\
\hline Lu.,+Aph., & $46.4 \mathrm{~d}$ & $40.8 \mathrm{bc}$ & $87.2 \mathrm{~b}$ & 46.3 \\
\hline Rh.,+ Lu., & $41.7 \mathrm{bc}$ & $34.5 \mathrm{bc}$ & $76.1 \mathrm{ab}$ & 27.6 \\
\hline Rh.,+ Aph., +Lu., & $45.1 \mathrm{~cd}$ & $35.0 \mathrm{c}$ & $80.1 \mathrm{~b}$ & 34.3 \\
\hline L S D & .000 & .000 & .035 & \\
\hline
\end{tabular}

Rh.,:Rhizobium Aph.,: Aphanocapsa Lu.,: Laurencia

Table 3 illustrates that all the treatments gave significant increase in whole plant fresh weight ranged between (11.3-56.0\%). The treatment of Rhizobium leguminosarum var, faba + Laurencia obtusa + Aphanocapsa albida gave the best result of whole plant fresh weight which reached $56.0 \%$ compared with control. Also all the treatments caused significant 
increase in shoot, root and whole plant dry weight (57.2-96.5\%). Laurencia obtusa + Aphanocapsa albida gave the best result and caused $96.5 \%$ inc

Table 3. Effect of some biofertilizers agents on fresh and dry weight (gm) of faba bean (Vicia faba L.)

\begin{tabular}{|c|c|c|c|c|c|c|c|c|}
\hline \multirow[t]{2}{*}{ Treatments } & \multicolumn{4}{|c|}{ Fresh weight (gm) } & \multicolumn{4}{|c|}{ Dry weight (gm) } \\
\hline & Shoot & Root & $\begin{array}{l}\text { Whole } \\
\text { plant }\end{array}$ & Increasing $\%$ & Shoot & Root & $\begin{array}{l}\text { Whole } \\
\text { plant }\end{array}$ & Increasing $\%$ \\
\hline Control & $9.4 \mathrm{a}$ & $4.2 \mathrm{a}$ & $13.7 \mathrm{a}$ & - & $1.62 \mathrm{a}$ & $1.2 \mathrm{a}$ & $2.8 \mathrm{a}$ & - \\
\hline Rh., & $10.4 \mathrm{ab}$ & $4.8 \mathrm{ab}$ & $15.2 \mathrm{a}$ & 11.3 & $2.1 \mathrm{ab}$ & $2.9 \mathrm{c}$ & $5.1 b c$ & 81.1 \\
\hline Aph., & $14.9 \mathrm{c}$ & $6.2 \mathrm{bc}$ & $21.1 \mathrm{bc}$ & 54.8 & $2.2 \mathrm{abc}$ & $2.2 \mathrm{~b}$ & $4.4 \mathrm{~b}$ & 57.2 \\
\hline Lu.,+Aph., & $12.8 \mathrm{bc}$ & $8.2 \mathrm{~d}$ & $20.3 b c$ & 48.5 & $2.9 \mathrm{c}$ & $2.6 \mathrm{bc}$ & $5.6 \mathrm{c}$ & 96.5 \\
\hline Rh.,+ Lu., & $13.7 \mathrm{c}$ & $4.9 \mathrm{ab}$ & $18.7 \mathrm{~b}$ & 36.7 & $2.1 \mathrm{ab}$ & $3.0 \mathrm{c}$ & $5.2 \mathrm{bc}$ & 82.5 \\
\hline $\begin{array}{l}\text { Rh.,+ Aph., } \\
\text { +Lu., }\end{array}$ & $14.0 \mathrm{bc}$ & $7.3 \mathrm{~cd}$ & 21.3 & 56.0 & $2.4 \mathrm{bc}$ & $2.7 \mathrm{bc}$ & $5.1 \mathrm{bc}$ & 780.7 \\
\hline L S D 0.05 & $.004^{* * *}$ & $.000 * * *$ & $.000 * * *$ & & $.007 * * *$ & $.000 * * *$ & $.000 * * *$ & \\
\hline
\end{tabular}

\section{Rh.,:Rhizobium Aph.,: Aphanocapsa $\quad$ Lu.,: Laurencia}

rease of whole plant dry weight comparing with the control.

Data in Figure 2 showed that application of Laurencia obtusa + Aphanocapsa albida caused the highest increase of total phenols content in Faba bean plant followed by Rhizobium leguminosarum var, faba treatment which reached $315 \%$ and $86 \%$ consequently.

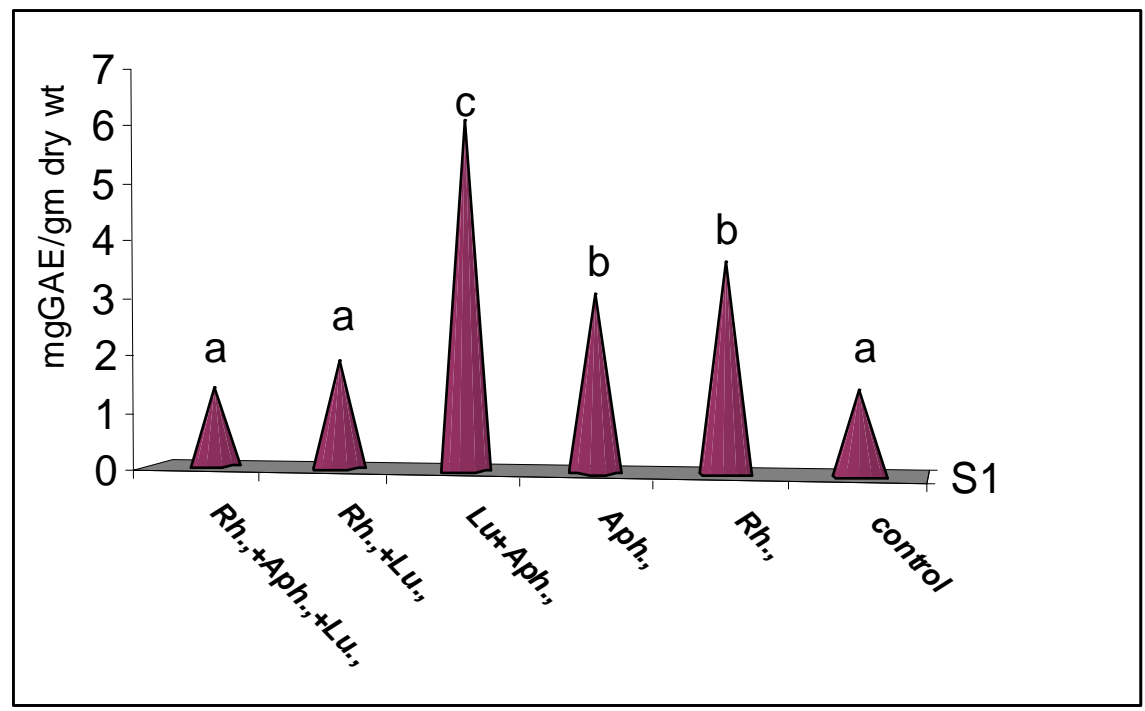

Figure 2. Effect of some biofertilizers agents on total phenole of faba bean (Vicia faba L.) 


\section{Macrothink Institute ${ }^{T M}$}

Figure 3 illustrates the mean percentage in nitrogen content in shoot root and whole plant of faba bean. The obtained results indicate that all the treatments caused increase in both of shoot, root and whole plant nitrogen content. Laurencia obtusa + Aphanocapsa albida caused the best result which reached $85.71 \%$ followed by Aphanocapsa albida which caused $80.95 \%$ increasing in comparison with control.

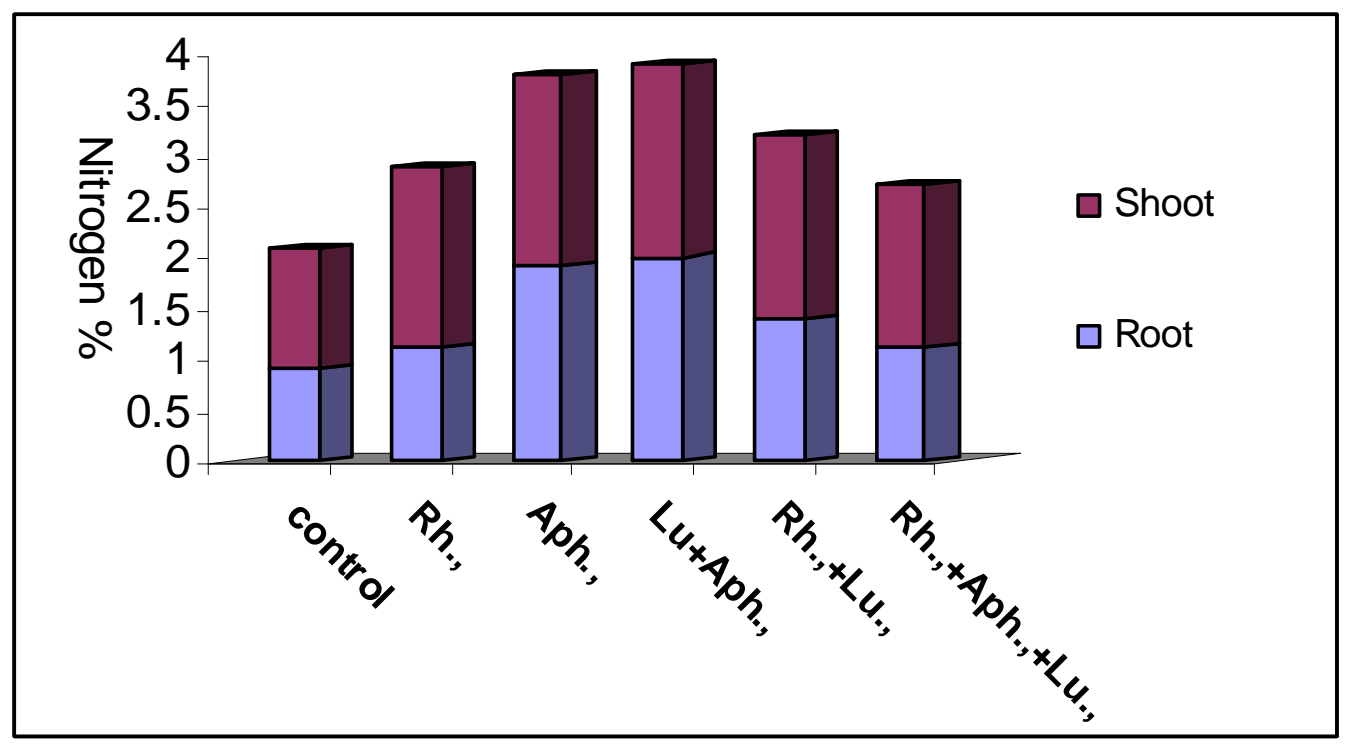

Figure 3. Effect of some biofertilizers agents on total nitrogen content of faba bean (Vicia faba L.)

\section{Discussion}

Obtained results indicate that Rhizobium leguminosarum var., faba, Laurencia obtusa and Aphanocapsa albida and their combinations have significant potential as biofertilizers agents to enhance the growth of Faba bean (Vicia faba L.,). These results are in agreement with Rokhzadi et al. (2008), El-Yazied et al. (2007), Sahu et al. (2012), Song et al. (2005), Sergeeva et al. (2002), Prasanna et al. (2002) , Strik et al. (2004) and Kevin Vessey, (2003). At the early growth stages the all used treatments increased plant height and number of leaves. These results are also obtained by Ravishankar, (2002), Guirgis et al. (2007), El-Barody et al. (2007) and Haroun and Hussein, (2003). After 90 days, at the end of the experiment, application of the studied microorganisms caused noticeable increase in plant length, fresh weight and dry weight of faba bean plant. These results are in agreement with those obtained by Faheed and Abd-El Fattah, (2008). Nitrogen content of treated plants were increased and these results are also noticed by Haroun and Hussein, (2003), Adam, (1999), Lozano et al. (1999), Subramaniyan and Malliga, (2011) and Saleh et al. (2008).

\section{Conclusion}

All biofertilizer treatments increased the growth parameters at all the tested plant stages while Laurencia obtusa + Aphanocapsa albida was the best tested treatment to enhance the plant growth parameters. Thus using combination of marine algae i.e; Laurencia obtusa and 
cyanobacteria i.e; Aphanocapsa albida as bioferrtilizers agents improved the growth of faba bean (Vicia faba L.) better than Rhizobium leguminosarum var. faba alone.

\section{Refrences}

Adam, M. S. (1999). The promotive effect of the Cyanobacterium Nostoc muscorum on the growth of some crop plants. Acta Microbiol. Polonica, 48,163-171.

Anonymous. (1990). Official Methods of analysis of official analytical chemistry (A.O.A.C.). Pub. by the Association of Analytical Chemistry, Inc., Arlington, West Virginia, USA.

Battacharyya, R. N., Pati, B. R. (2000). Growth behaviour and Indole Acetic Acid (IAA) production by a Rhizobium isolated from root nodules of Alyscarpus vaginalis DC. Acta Microbiol. Immunol. Hung, 47(1), 41-51.

El-Barody, G. S., Moussa, M.Y. Shallan, A. M., Ali, A. M., Sabh, Z. A. Shalaby, A. E. (2007). Contribution to the Aroma, Biological Activities, Minerals, Protein, Pigments and Lipid Contents of the Red Alga, Aspara gopsis taxiformes (Delie) Trevisan. Journal of Applied sciences research, 3(12), 1825-1834.

El-Yazid, A. A., Abou-Ali, H. A., Mady, M. A., \& Moussa. S. A. M. (2007). Enhancing growth, productivity and quality of squash plants by using phosphate dissolving microorganisms (bio phosphor) combined with boron foliar spray. Res. J. Agric. Biol. Sci., 3(4), 274-286.

Faheed, A. F., \& Abd-El Fattah, Z. (2008). Effect of Chlorella vulgaris as biofertilizer on growth parameters and metabolic aspects of Lettuce plant. Journal of Agriclture and Social Sciences, 4(4), 165-169.

Franche, C., Lindström, \& K., Elmerich. (2009). Nitrogen- fixing bacteria associated with leguminous and non-leguminous plants. Plant and soil, 321, 35-39. http://dx.doi.org/10.1007/s11104-008-9833-8

Haroun, A.S. \& Hussein, M.H. (2003). The promotive effect of algal biofertilizers on growth, protein pattern and some metabolic activities of Lupinus terms plant grown in siliceous soil. Asian Journal of plant and Sciences, 2(13), 944-951. http://dx.doi.org/10.3923/ajps.2003.944.951

Kevin Vessey, J. (2003). Effect of Rhizobacterial biofertilizer on plant growth. Plant and Soil, 255(2), 571-586). http://dx.doi.org/10.1023/A:1026037216893

Lozano, M. S., Verde Star, J., Maitic, P.K., Orandy, C.A., Gaona, R. H., Aranada H. E., \& Rojas, G. M. (1999). Effect of an algal extract and several plant growth regulators on the nutritive value of Potatoes (Solanum tuberosum L. Var. Gigant), archives hat in oamericanos de Nuticion, 49, 166-170.

Meeks, J. C. \& Elhai J. (2002). Regulation of cellular differentiation in filamentous cyanobacteria in free- living and plant associated symbiotic growth states. Microbiological Molecular Biology Review, 66, 94-121. http://dx.doi.org/10.1128/MMBR.66.1.94-121.2002 
Prasanna, R., Joshi, M., Rana, \& A., Nain, L. (2020). Nodulation of IAA production in cyanobacteria by tryptophan and light. Polish Journal of Microbiology, 59(2), 99-105.

Ravishankar, R. (2002). Effect of cyanobacterial extract Phormidium valderianum BDU 30501 on growth and yield of Blackgram (Vigna mungo T-9 variety), M.Sc.,Disserlation. Bahrathiadasan University, Trichy, Tamilnadu.

Rajula, G. \& Padmadevi. S. N. (2002). Effect of industrial effluents with auth and with blue green algae on the growth and biochemical contents of the seedling of Helianthus annus L. Asian Journal of microbial biotechnology and Environmental Science, 2(3-4), 151-154.

Rippka, R. (1988). Isolation and purification of cyanobacteria. In: Glazer, A.N. (Ed.), Methods in Enzymology. In: Glazer, A.N. (Ed.), Cyanobacteria, 167. Academic Press, San Diego, 3-28.

Rodrigues, A. A., Stella, A. A., Storni, M. M., Zulpa, G., \& Zaccaro, M. C. (2006). Effect of Cyanobacterial extracellular products and gibberellic acid on salinity tolerance in Oryza sativa L., Saline system, 2, 7. http://dx.doi.org/10.1186/1746-1448-2-7

Rokhzadi, A., Asgharzadeh, A., Darvish, F., Nour-Mohammadi, G., \& Majidi, E. (2004). Influence of plant growth promoting rhizobacteria on dry matter accumulation and yield of chickpea. American-Eurasian Journal of Agricultural \& Environmental Sciences, 3(2), 253-257.

Sahu, D., Priadrshni, I., \& Rath, B. (2012). Cyanobacteria-as potential biofertilizers. CIB Tech Journal of Microbiology, 1(2-3), 20-26.

Saleh, M. M., Awad, N. E., Abou-Zeid, A. H., Anderson, K., \& Glombitza, K. W. (1993). Antiviral and immunological activity of glycoproteins from marine brown alga Colpomenia sinuosa, Amino Acids, 5(1),152.

Sergeeva, E., Liaimer, A., \& Bergman, B. (2002). Evidence for production of the phytohormones indole-3-acetic acid by Cyanobacteria, Planta, 215, 229-238. http://dx.doi.org/10.1007/s00425-002-0749-x

Singleton, V.L \& Rossi, J. A. (1965). Colorimetry of total phenolics with phosphomolybdic-phosphotungstic acid reagents. Am. J. Enol. Viticul., 16, 144-158.

Sokal, R.R. \& Rohlf F.J. (1995). Biometry: the principles and practice of statistics in biological research.3rd ed. W.H. Freeman and company New yourk, p 937

Song, T., Martenson, Eriksson, T., Zheng, W., \& Rasmussen. U. (2005). Bidiversity and second variation of the cyanobacterial assemblage in a rice paddy fields in Fujian, China. The Federation of European Materials societies. Microbial Ecology, 54, 131-140. http://dx.doi.org/10.1016/j.femsec.2005.03.008

Sprent, J.I. (2007). Evolving ideas of legume evolution and diversity: a taxonomic perspective on the occurrence of nodulation. New Phytologist, 174, 11-25. http://dx.doi.org/10.1111/j.1469-8137.2007.02015.x 


\section{Macrothink

Stanier, R. Y., Kunisawa, R., Mandel, M., \& Cohen-Bazire G.(1971). Purification and properties of unicellular blue-green algae (order Chroococcales). Bacteriol. Rev., 35, 171-205.

Strik, w. A., Arthur, G. D., Lourens, A. F., Novok, O., Strand M., \& Van-Staden, J. (2004). Changes in seaweed concentrates when stores at an elevated temperature, Journal of Applied Phycology, 16, 31-39. http://dx.doi.org/10.1023/B:JAPH.0000019057.45363.f5

Subramaniyan,V., Malliga, P. (2011). Effect of Cyanobith biofertilizer as basal and spray on Zea mays (Corn) cultivation. International Journal of Environmental Science, 2, 2-12.

Zarrouk, C. (1966). Contribution à l'étude d'une cyanophycée influencée de divers facteurs physiques et chimiques sur la croissance et la photosynthèse de Spirulina maxima (Setch. et Gardner) GeitlerUniversity of Paris, Paris, France. (PhD Thesis).

Thamida Begum, Z. N. \& Mandal, R. Saiful, I. (2011). Effect of Cyanobacterial biofertilizer on the growth and yield components of two HYV of rice. Journal of Algal Biomass Utilization, 2(1), 1-9.

Thirumaran, G., Arumugam, M., Arumugam, R., \& Anantharaman, P. (2009). Effect of Seaweed Liquid Fertilizer on Growth and Pigment Concentration of Abelmoschus esculentus (1) medikus American-Eurasian Journal of Agronomy, 2(2), 57-66. 